\title{
THE FIRST WORLD WAR AS DEPICTED IN HISTORY TEXTBOOKS (ARGENTINA, BRAZIL, CHILE, MEXICO, AND THE UNITED KINGDOM)
}

DOI: http://dx.doi.org/10.1590/2236-3459/69005

\author{
Rogério Justino \\ Instituto Federal de Educação, Ciência e Tecnologia do Tocantins, Brasil.
}

\author{
Décio Gatti Júnior \\ Universidade Federal de Uberlândia, Brasil.
}

$\cos 80$

\begin{abstract}
This paper communicates the results of research in the area of the History of School Subjects, the object of which is the way the theme of the First World War has been depicted in textbooks used in Brazil and abroad. A premise of this study is that textbooks are important tools in school life, contributing to the vision students have of the world. As such, five different textbooks used in Argentina, Brazil, Chile, Mexico, and the United Kingdom were analyzed. It was observed that there was predominance of a narrative based on the explanatory triad - antecedents, development, and consequences; emphasis on an androcentric discourse, backed up with great names and deeds, with a Eurocentric bias; and dissonance in the interpretations made in the books analyzed, and only in the British book did the conflict occur as a result of an accident.

Keywords: history of school subjects, textbook, First World War.
\end{abstract}

\section{A PRIMEIRA GUERRA MUNDIAL NA ESCRITA DE LIVROS DIDÁTICOS DE HISTÓRIA (ARGENTINA, BRASIL, CHILE, MÉXICO E REINO UNIDO)}

\begin{abstract}
Resumo
Este artigo comunica os resultados de pesquisa no âmbito da História das Disciplinas Escolares, cujo objeto se referiu a forma como o tema da Primeira Guerra Mundial foi abordado em livros didáticos utilizados no Brasil e no exterior. Partiu-se da ideia de que os livros didáticos são importantes ferramentas no cotidiano escolar, com contribuição para que os estudantes construam suas visões de mundo. Para tanto, foram analisados cinco diferentes livros didáticos de História, que têm sido utilizados na Argentina, no Brasil, no Chile, no México e no Reino Unido. Constatou-se que houve: predominância de uma narrativa baseada na tríade explicativa - antecedentes, desenvolvimento e consequências; ênfase em um discurso androcêntrico, sustentado nos grandes nomes e feitos, com viés eurocêntrico; dissonância nas interpretações construídas nos livros analisados, sendo que apenas no britânico, o conflito ocorreu como o resultado de um acidente. Palavras-chave: história das disciplinas escolares, livro didático, Primeira Guerra Mundial.
\end{abstract}




\section{LA PRIMERA GUERRA MUNDIAL EN LA ESCRITURA DE LIBROS DIDÁCTICOS DE HISTORIA (ARGENTINA, BRASIL, CHILE, MÉXICO Y REINO UNIDO)}

\section{Resumen}

Se trata de la comunicación de resultados de investigación en el ámbito de la Historia de las Disciplinas Escolares, cuyo objeto se refirió a la forma como el tema de la Primera Guerra Mundial fue abordado en libros didácticos utilizados en Brasil y en el exterior. Se partió de la idea de que los libros didácticos son importantes herramientas en el cotidiano escolar, con contribución para que los estudiantes construyan sus visiones de mundo. Para esto, fueron analizados cinco diferentes libros didácticos de Historia, que han sido utilizados en Argentina, en Brasil, en Chile, en México y en el Reino Unido. Se constató que hubo: predominancia de una narrativa basada en la triada explicativa -antecedentes, desarrollo y consecuencias; énfasis en un discurso androcéntrico, sustentado en los grandes nombres y hechos, con un sesgo eurocéntrico; disonancia en las interpretaciones construidas en los libros analizados, siendo que apenas en el británico, el conflicto ocurrió como resultado de un accidente.

Palabras-clave: historia de las disciplinas escolares, libro didáctico, Primera Guerra Mundial.

\section{LA PREMIÈRE GUERRE MONDIALE DANS L'ÉCRITURE DES MANUELS D'HISTOIRE (ARGENTINE, BRÉSIL, CHILI, MEXIQUE ET ROYAUME-UNI)}

\section{Résumé}

II s'agit de la communication des résultats de la recherche dans le cadre de l'histoire des disciplines scolaires dont l'objet s'est rapporté à la façon comme le thème de la premère guerre mondiale a été traité dans les manuels utilisés au Brésil et à l'étranger. On a démarré par l'idée de que les manuels sont des outils importants dans le quotidien scolaire, avec sa contribution pour qui les étudiants construisaient ses visions de monde. À cette fin, cinc manuels d'histoire différents qui ont été utilisés en Argentine, au Brésil, au Chili, au Mexique et au Royaume-Uni ont été analysés. On a constaté qu'il y a eu: la prédominance d'un récit fondé sur la tríade explicative - antécédents, développement et conséquences; l'accent sur un discours androcentrique soutenu par les grands noms et les exploits, avec un biais eurocentrique; la dissonance entre les interpretations construites dans les manuels analysés, étant donné que seulement dans le manuel britannique le conflit est arrivé à cause d'un accident.

Mots clés: histoire des disciplines scolaires, manuel, Première Guerre Mondiale. 


\section{Introduction}

C urrently, the possibilities for access to historical information have achieved a breadth little imagined before, whether through traditional means, in consulting books and articles published in magazines and journals, or more recently created means, such as films, especially in the form of documentaries and historical films, which deal with the most diverse themes of history, or, moreover, in the last ten or twenty years, Internet, which has allowed access to vast information regarding different matters of the past and the present.

However, with rare exceptions and by means of few innovations, in most school institutions throughout the world with traditional forms of temporal and spatial organization, the platform of access to information, which includes historical information, continues to be the school textbook, as explained by Foster (2006, p. 157), "In short, the standard conventional textbook continues to dominate classroom instruction and teachers rely on a single textbook as the principle source of knowledge".

In this regard, Apple (1995, p. 85) affirms that in the United States in the 1990s, calculations were that approximately $75 \%$ of classroom time was used in work with textbooks and that $90 \%$ of homework time was likewise bound up with them.

Thus, in addition to the school textbook playing this central role in the life of teachers and students in the classroom, in the case of Brazil, in the middle of the 1990s, it was the most highly sold product for publishing companies in the country. According to data supplied by the Brazilian Council of Books (Câmara Brasileira do Livro - CBL), in that period, school textbooks represented $61 \%$ of books sold and $55 \%$ of revenue in the publishing sector (CÂMARA BRASILEIRA DO LIVRO - CBL, 1996, p. 2).

However, in comparison, for publishers in France in 1996, the same market niche, school textbooks, concentrated approximately $20 \%$ of the publishing business (CBL, 1996, p. 2). For their part, United States publishers in 1980 concentrated approximately $25 \%$ of their business in the branch of school books, which, in absolute numbers of that time, reached 1.5 billion dollars (APPLE, 1995, p. 90).

In any case, although there are substantive differences between consumption of books in general and consumption of school textbooks in different countries, it is possible to affirm, without much doubt, that in classrooms throughout the world, textbooks have been and still are a central object of school culture. They not only support the explicit content of the school subjects but are also, in large part, a teaching instrument that contributes to class organization according to pedagogical conceptions adapted to the school structure spread throughout the world.

School textbooks have been highly used in studies carried out in recent decades in the field of History of Education. They have often been perceived as cultural objects that carry the signs of who produced them, including authors, publishers, markets, etc. Thus, studying them allows the historian to access the set of contents to be taught, which, in accordance with their form of presentation, constitutes an educational strategy and a supposedly accurate view of the world. In this regard, Chopin (2004, p. 557) states that

[...] the image of society presented by textbooks corresponds to a reconstruction in line with different motivations, according to time and place, and it has the common characteristic of presenting society in broad outlines more in the way as those who conceived the textbook would like it to be than as it really is. Authors of textbooks are not simple spectators of their time; they claim another status, that of an agent. 
In this line of reasoning, it is fitting to add, even in a summarized fashion, the reflections of Chervel (1990). In the sphere of the historical-educational world, he demarcates important differences between ideal purposes and real purposes. The former, related to fixed objectives, may be better understood in the relationship between school and society in accordance with the variety of political and cultural projects they have. In addition, the sources of investigation of these purposes include the educational ideas conveyed, the teaching legislation approved and replaced, the news conveyed by the press in a general way and the pedagogical news in particular, the teaching programs, the school manuals and textbooks, the class registers, etc.

In contrast, real purposes consist of the universe of the school and even the classroom, which are the places to be investigated. However, the sources for examining this real teaching are not always easily found, because they include student notebooks, school tests, iconography, school journalism, and, when possible, the construction of written documents from oral testimony.

Based on these general presuppositions regarding school textbook and regarding the objectives (ideals) they bear, we decided to seek information in regard to the First World War in school textbooks and in the wars these textbooks deal with ane hundred years since the beginning of the First World War, which came to pass in 2014. This was an initiative taken as of the stimulus received through the theme proposed in the 36th edition of the International Standing Conference for the History of Education, which took place in the Institute of Education of the University of London, precisely in 2014, under the theme Education, War and Peace. To achieve the objectives of the study, we establish a comparative survey based on examination of textbooks used in recent years in Argentina, Brazil, Chile, Mexico, and the United Kingdom.

In the case of the first four countries, the choice was made not only due to availability of textbooks for high school use and due to the ease of understanding the languages involved, Portuguese and Spanish, but also because the countries chosen are in Latin America and were not central to the First World War.

In the case of the United Kingdom, as for the previously mentioned textbooks, the availability of copies for high school use and understanding of the language were important, but there was also the possibility of finding discursive elements of an opposing nature as compared to Latin American books, as well as the fact that the United Kingdom was a central nation in the conflict that was the theme of study. Basic information on the school textbooks examined in this study is shown in Table 1.

Table 1 - Listing of school textbooks analyzed.

\begin{tabular}{|l|l|l|l|l|l|}
\hline Country & \multicolumn{1}{|c|}{ Authors } & \multicolumn{1}{c|}{ Title } & \multicolumn{1}{c|}{ City } & Publisher & Year \\
\hline Argentina & $\begin{array}{l}\text { Felipe Pigna, Carlos Mora, } \\
\text { Julio Bulacio e Guilhermo } \\
\text { Cao }\end{array}$ & $\begin{array}{l}\text { History. The } \\
\text { contemporary world }\end{array}$ & $\begin{array}{l}\text { Buenos } \\
\text { Aires }\end{array}$ & A-Z & 2010 \\
\hline Brazil & $\begin{array}{l}\text { Patrícia Ramos Braick e } \\
\text { Myriam Becho Mota }\end{array}$ & $\begin{array}{l}\text { History: from the cave } \\
\text { to the third milenniumb }\end{array}$ & São Paulo & Moderna & 2013 \\
\hline Chile & $\begin{array}{l}\text { Humberto Sánchez Córdova, } \\
\text { Lilia Estela Romo Medrano, }\end{array}$ & Universal Historyc & Mexico, DF & Pearson & 2009 \\
\hline
\end{tabular}




\begin{tabular}{|c|c|c|c|c|c|}
\hline Country & Authors & Title & City & Publisher & Year \\
\hline & $\begin{array}{l}\text { Rosa María Parcero Lópes, } \\
\text { Efraín Becerra Juárez e } \\
\text { Katyna Goytia Rodríguez }\end{array}$ & & & & \\
\hline Mexico & Carlos Alvear Acevedo & $\begin{array}{l}\text { Contemporary } \\
\text { Universal Historyd }\end{array}$ & Mexico, DF & Limusa & 1999 \\
\hline $\begin{array}{l}\text { United } \\
\text { Kingdom }\end{array}$ & Alan Farmer & $\begin{array}{l}\text { An Introduction to } \\
\text { Modern European } \\
\text { History 1890-1990 }\end{array}$ & London & $\begin{array}{l}\text { Hooder } \\
\text { Education }\end{array}$ & 2009 \\
\hline
\end{tabular}

${ }^{a}$ From the original in Spanish: Historia. El mundo contemporâneo.

${ }^{b}$ From the original in Portuguese: História: das cavernas ao terceiro milênio.

c From the original in Spanish: Historia Universal.

d From the original in Spanish: Historia Universal Contemporánea.

Source: Prepared by the authors.

In a comparative survey - which involved analysis of texts, pictures, relevance given to women, and discursive strategies - the elements of continuity, similarity, and differences among the books analyzed were highlighted. Among the criteria for choosing the school textbooks, we chose those that were available in the collection of the authors through acquisitions made recently and directly in bookstores of the different countries of reference. This denotes the feature of current use in the teaching systems of the different countries of reference. In addition, they are titles that deal with Universal History, World History, or General History directed at the secondary level of the schooling process, that which normally encompasses the end of so-called basic or fundamental education and precedes higher education. In Brazil, this level is called ensino médio (intermediate schooling).

Thus, in general, we sought to analyze the content related to the First World War in school textbooks that were easily accessible to the local population, which suggests regular consumption of the books, for we consider that if acquisition occurred through digital media or even through access to public collections, one could find school textbooks that would not be easily accessible to students and, therefore, would be little used in school institutions.

Another factor considered was, whenever possible, to choose school textbooks that had been written and published by authors and companies from the same country that was under analysis. An exception was the school textbook from Chile. It was not possible to find books in the large bookstores that were from local publishers, and the work recommended by sales personnel was from the publisher Pearson, of English origin, with Mexican authors. At any rate, it was interesting to carry out analysis of this work because, in contrast to the others, it presents the contents without dealing with or reporting the contents of General History, with events and situations experienced in Chile itself.

In short, we begin this article with the effort of identifying the relevance that each chosen school textbook conferred to the theme of the First World War. We then examine the sources through consideration of the question: if the war is European, why is it called a world war? In the third part, called "A bloodless war", we discuss the ways in which the contents examined in the works referred to, and also in school textbooks in general, 
eliminate the issue of death in belligerent conflicts, which were treated nearly always through a sanitized narrative. Moreover, we seek to analyze the narrative in regard to the participation of women in the conflict, which is undertaken in the fourth part of the article. Finally, in the fifth and last part, we make a comparison among the forms of narrating the conflict in a general way, collating it with excerpts from the books. In this regard, including the work from the United Kingdom was important, since it presented a contrast that distanced it from the contents exhibited in the works from Latin American countries. Finally, we make some comments of a general nature.

\section{The relevance given to the theme of the First World War}

For the purpose of perceiving the relevance given to the First World War in the works analyzed, we initially examined each of the school textbooks with the objective of determining the absolute number of pages and the percentage of the total number of pages of each one of the works that refer to the specified theme. A synthesis of the results is shown in Table 2.

Table 2 - School textbooks analyzed, with an emphasis on the contents related to the theme of the First World War.

\begin{tabular}{|c|c|c|c|c|c|c|c|c|}
\hline Country & Authors & Main title & Publisher & $\begin{array}{l}\text { Year } \\
\text { of } \\
\text { publi- } \\
\text { cation }\end{array}$ & $\begin{array}{l}\text { Pages } \\
\text { on the } \\
\text { First } \\
\text { World } \\
\text { War }\end{array}$ & $\begin{array}{c}\text { Number } \\
\text { of } \\
\text { pages }\end{array}$ & $\begin{array}{c}\text { Pages } \\
\text { of the } \\
\text { total } \\
\text { work }\end{array}$ & $\%$ \\
\hline Argentina & $\begin{array}{l}\text { Felipe Pigna; } \\
\text { Carlos Mora; } \\
\text { Julio Bulacio; } \\
\text { Guilhermo Cao. }\end{array}$ & $\begin{array}{l}\text { History. } \\
\text { The } \\
\text { contempo- } \\
\text { rary world }\end{array}$ & $A-Z$ & 2010 & $83-97$ & 15 & 332 & 4.6 \\
\hline Brazil & $\begin{array}{l}\text { Patrícia Ramos } \\
\text { Braick; Myriam } \\
\text { Becho Mota. }\end{array}$ & $\begin{array}{l}\text { History: } \\
\text { from the } \\
\text { cave to the } \\
\text { third } \\
\text { milenniumb }\end{array}$ & Moderna & 2013 & $\begin{array}{l}453- \\
458\end{array}$ & 6 & 631 & 0.9 \\
\hline Chile & $\begin{array}{l}\text { Humberto } \\
\text { Sánchez } \\
\text { Córdova; Lilia } \\
\text { Estela Romo } \\
\text { Medrano; } \\
\text { Rosa María } \\
\text { Parcero Lópes; } \\
\text { Efraín Becerra } \\
\text { Juárez; Katyna } \\
\text { Goytia } \\
\text { Rodríguez. }\end{array}$ & $\begin{array}{l}\text { Universal } \\
\text { Historyc }\end{array}$ & Pearson & 2009 & $108-124$ & 17 & 308 & 5.6 \\
\hline Mexico & $\begin{array}{l}\text { Carlos Alvear } \\
\text { Acevedo }\end{array}$ & $\begin{array}{l}\text { Contempo- } \\
\text { rary } \\
\text { Universal } \\
\text { Historyd }^{d}\end{array}$ & Limusa & 1999 & $246-254$ & 10 & 306 & 3.3 \\
\hline $\begin{array}{l}\text { United } \\
\text { Kingdom }\end{array}$ & Alan Farmer & $\begin{array}{l}\text { An } \\
\text { Introduction }\end{array}$ & $\begin{array}{l}\text { Hooder } \\
\text { Education }\end{array}$ & 2009 & $\begin{array}{l}35-79 \\
89-107^{e}\end{array}$ & 63 & 307 & 20.5 \\
\hline
\end{tabular}




\begin{tabular}{|l|l|l|l|l|l|l|l|l|}
\hline Country & Authors & Main title & Publisher & $\begin{array}{c}\text { Year } \\
\text { of } \\
\text { publi- } \\
\text { cation }\end{array}$ & $\begin{array}{c}\text { Pages } \\
\text { on the } \\
\text { First } \\
\text { World } \\
\text { War }\end{array}$ & $\begin{array}{c}\text { Number } \\
\text { of } \\
\text { pages }\end{array}$ & $\begin{array}{c}\text { Pages } \\
\text { of the } \\
\text { total } \\
\text { work }\end{array}$ & $\%$ \\
\hline & & $\begin{array}{l}\text { to Modern } \\
\text { European } \\
\text { History } \\
1890-1990\end{array}$ & & & & & \\
\hline
\end{tabular}

a From the original in Spanish: Historia. El mundo contemporâneo.

b From the original in Portuguese: História: das cavernas ao terceiro milênio.

${ }^{c}$ From the original in Spanish: Historia Universal.

d From the original in Spanish: Historia Universal Contemporánea.

e The theme of the First World War was interrupted by treatment of the Russian Revolution (p. 80-88).

Source: Prepared by the authors.

It may be deduced from the data presented in Table 2 that there was a more intense treatment of the First World War in the British school textbook, followed by the textbooks used in Chile, in Argentina, in Mexico, and in Brazil. A great difference can be seen between the space devoted to the theme in the British book and the Brazilian book, with percentages of $20.8 \%$ and $0.9 \%$, respectively, and absolute number of pages of around 63 in the British book and six in the Brazilian.

The quantitative observation is an important index because it denotes how much authors and publishers were willing to dedicate themselves to the theme of the First World War. As a result, given that these are school textbooks connected with secondary education, the space given to a certain subject in most cases ends up prescribing to the teacher, and consequently to the students, the time that will be dedicated to that subject in the classroom. Thus, it can be seen that in Brazilian schools in which the school textbook under analysis is used, the relevance given to the conflict may be quite small.

This description of the Brazilian book differs greatly from the emphasis given in the British book, which dedicates approximately $20 \%$ of its content to the theme of the First World War, which indicates the relevance granted to the subject by the author and publisher. Apparently, even though we have not had access to the official teaching programs of the different countries, the data shown in Table 2 allow us to notice the emphasis that each one of them places on determined subjects, since absence of information is notable, and even the limitations related to certain contents are also revelatory.

Thus, we conclude with the observation that the theme of the First World War is much more striking in the British book than in the books analyzed and used in the Latin American countries in reference. Nevertheless, the consequences of this more succinct approach in the books used in the Latin American countries involved in this investigation are deleterious because the books cover over the real number of people who lost their lives in the conflict and even the difficulties in the post-war period, which, among other aspects, resulted in the outbreak of a new and important conflict.

\section{If the war is European, why is it called a world war?}

This study sought references on the participation of each one of the countries in 
which the school textbooks were published, that is, if Argentina, Brazil, Chile, Mexico, and the United Kingdom were cited, and how they were mentioned in the texts.

The United Kingdom, due to its centrality, was mentioned in all the works analyzed, only with changes in nomenclature. In the British book, the nation is referred to as the United Kingdom, whereas in the Latin American books, the term varied between Great Britain, the United Kingdom, and England.

In the British book, the nation is placed as the central element that gave rise to all the efforts to avoid the outbreak of war, using all diplomatic means, and only when these alternatives failed, did the United Kingdom declare war on the Triple Alliance.

According to Hobsbawm (2008), although most of the combat occurred on European soil, Argentina, Brazil, Chile, and Mexico are countries that were also affected by the conflict, albeit in different ways. Even so, none of the books studied in this survey refer to the consequences they suffered as nations.

The narrative of the First World War in the Latin American textbooks analyzed excludes the countries from the conflict, confirming a vision of an exclusively European war. This conception contributes so that questions routinely occur in classrooms, such as "If this is a European war, why is it called a world war?".

In this respect, both the illustrations and the text join in depicting the distance of the First World War from Latin American nations, and maps are a common resource for working with conflicts in textbooks. Table 3 shows the number of maps used in each one of the works, with a predominance of maps of Europe. Only in the British book (FARMER, 2009) are there two maps placing Africa in the center. Latin America is not represented in any of them.

Table 3 - Number of maps related to the theme of the First World War in the textbooks surveyed by country of publication.

\begin{tabular}{l|c}
\hline \multicolumn{1}{c|}{ Country } & $\begin{array}{c}\text { Number of maps related to the content of } \\
\text { the First World War }\end{array}$ \\
\hline Argentina & 01 \\
\hline Chile & 03 \\
\hline Brazil & 03 \\
\hline Mexico & 00 \\
\hline United Kingdom & 13 \\
\hline
\end{tabular}

Source: Prepared by the authors.

The same situation of concentrating the discussion on Europe seen in the maps was repeated in analysis of the pictures and the written text itself. However, it was possible to find some references to Latin American countries, such as occurred in the British book when it discussed the role of Mexico, as shown in the following text. 
This excerpt shows that Mexico had relevance in the belligerent scenario, at least for the Germans; however, this event is not noted in the Mexican book, which preferred the European figures to narrate the war. In the Mexican book, for its part, the following excerpt appeared, citing some Latin American countries

[...] Allies consisting of the following nations: Russia, France, Serbia, England, Belgium, Luxemburg, Montenegro, Japan, England, [...], Panama, Cuba, [...], Brazil, Guatemala, Nicaragua, Costa Rica, Haiti and Honduras. In contrast, Peru, Ecuador and Uruguay only broke off diplomatic relations with the Central Empires (ALVEAR ACEVEDO, 1999, p. 249)1.

However, this is a citation, which was not accompanied by any explanation about the forms of participation or even the consequences of the First World War for these nations; they simply made up a list of member countries of the Triple Entente. Furthermore, in reference to Latin American countries, the Chilean book contained the information that "the second phase began in March 1917 when the USA intervened and the Iberian American countries abandoned neutrality in favor of the Entente countries" (SÁNCHEZ CÓRDOVA et al, 2009, p. 117)².

Even without a great deal of emphasis, it is evident that these excerpts lead to the perception that Latin American countries had some relation to the conflict; after all, markets were connected and even though participation was not in military terms, consequences remained in various areas, including the economic area, as shown by Albert (2002) upon citing the impacts on the banking system of Latin America:

In Latin America the "tug" from London had immediate and devastating consequences. There were runs on the banks and between $2-4$ August, bank "holidays" were declared in Argentina, Peru and Brazil. Chile was not immune to the financial panic (ALBERT, 2002, p. 42).

In Brazil, for its part, in addition to these effects, Fausto (2012) points to industrialization for replacement of imports. Mexico constitutes a strategic region for the central powers, "With its almost 2,000-mile border with the United States, Mexico became an important theater of covert activity in World War I" (PILCHER, 2013, p. 479). These activities, in Mexican territory, gained impetus after its government refused the German proposal of cooperation with the central powers.

Germany attempted to use Mexico as a base for espionage activities against the United States. Agents built a radio station in Ixtapalapa, a suburb of Mexico City, and disseminated anti-American propaganda to Mexican audiences (PILCHER, 2013, p. 480)

However, even though there is academic literature that demonstrates the relevance of the participation or even the consequences borne by Latin American nations as a result of the First World War, textbooks, through their texts, maps, and pictures and,

\footnotetext{
1 From the original in Spanish: "[...] Aliados, que se formó por las siguientes naciones: Rusia, Francia, Serbia, Inglaterra, Bélgica, Luxemburgo, Montenegro, Japón, Inglaterra, [...], Panamá, Cuba, [...], Brasil, Guatemala, Nicaragua, Costa Rica, Haití y Honduras. Rompieron sus relaciones diplomáticas con los Imperios Centrales, a su vez: Perú, Ecuador y Uruguay".

2 From the original in Spanish: "La segunda fase comenzó en marzo de 1917. Cuando intervino Estados Unidos y los países ibero-americanos abandonaron la neutralidad en favor de los países de la Entente".
} 
more precisely, through their silence on the question, contribute to the question: if this is a European war, why is it called a world war?

\title{
A bloodless war
}

Construction of the conflict throughout the five textbooks contrasts with the reality of a true war. In this regard, in the British book we find:

\begin{abstract}
About 10 million men died in total. A further 5 million civilians may have died from diseases related to food shortages. A great influenza epidemic in 1918-19, which killed millions of people worldwide, added to the misery (FARMER, 2009. p. 93).
\end{abstract}

Nevertheless, in spite of reporting the number of dead and wounded, the path chosen by the author of the British book and by the other authors of the textbooks analyzed was that of not focusing on human losses or on the day-to-day horrors of the battlefields. For their part, in the Brazilian book, upon recounting the entrance of the Ottoman Empire in the conflict, the authors use the adjective "resentful" to qualify the relationship between two States: "The Ottoman Empire, enemy of Russia, and Bulgaria, with old resentments against Serbia, joined Germany" (BRAICK; MOTA, 2013, p. 456) 3 $^{\text {. In }}$ the Argentinian book, combat does not occur among soldiers, with personal and family histories, feelings, or fear, but is rather described in the following manner:

The armies fought on different fronts. On the western front, French and British confronted Germans. And on the Eastern front, Germans, Austro-Hungarians, and, later, Bulgarians fought Russians and Serbians (PIGNA et al, 2010, p. 91)4.

From analysis of these narratives, we perceive that, in general, the textbooks analyzed portray the First World War detached from the consequences for the life of the people involved in it, such as soldiers and their families, and emphasized the role played by nations. This bloodless war is quite distant from the description of Hobsbawm upon citing the western battle front and the significant number of casualties that occurred.

This was the 'Western Front', which became a machine for massacre such as had probably never before been seen in the history of warfare. Millions of men faced each other across the sandbagged parapets of the trenches under which they lived like, and with, rats and lice. [...] The French lost almost 20 per cent of their men of military age [...] Even the apparently modest losses of the USA (116,000, against the 1.6 millions of French, the almost 800,000 of British, the 1.8 millions of Germans) actually demonstrate the murderous nature of the Western front [...] (HOBSBAWM, 2008, p. 33).

This type of discursive construction contained in the textbooks analyzed is in accord with the reflections of Chopin (2004, p. 557), who affirms that:

The textbook is not a simple mirror: it modifies reality to educate new generations, providing an image that is deformed, schematized, modeled, frequently in a favorable manner: actions contrary to ethics are nearly always punished in an

\footnotetext{
${ }^{3}$ From the original in Portuguese: "O Império Otomano inimigo da Rússia, e Bulgária, com ressentimentos antigos contra a Sérvia, se juntaram à Alemanha"

${ }^{4}$ From the original in Spanish: "Los ejércitos combatieron en distintos frentes. En el frente occidental, se enfrentaron franceses y británicos contra alemanes. En el frante oriental combatieron alemanes, austrohúngaros y, algo más tarde, búlgaros, contra rusos y sérvios".
} 
exemplary manner; social conflicts, criminal acts or day-to-day violence are systematically silenced.

It should be noted that in the textbooks analyzed, pictures have a merely illustrative function; they are not problematized but show only the scenes and soldiers in the battlefield. In the Brazilian book, there are two pictures of soldiers in trenches, a characteristic feature of the First World War, with the following captions: "The First World War was a conflict that made wide use of a system of trenches. In the photo, Bulgarian soldiers during a meal in a trench at the battle front in the north of Bulgaria in 1917" (BRAICK; MOTA, 2013, p. 453) ${ }^{5}$ and "French soldiers having a meal in the trench during the First World War" (BRAICK; MOTA, 2013, p. 457) ${ }^{6}$.

The Argentinian book carries a figure on the first page, below the chapter title, with the caption "British soldiers in trenches captured by the Germans" (PIGNA et al, 2010, p. $83)^{7}$. There are four soldiers seated on the ground and, in the upper part of the photo, in the background, it is possible to see part of a hand and a boot that suggests a soldier killed on the battlefield. In all observations made, this was the only pictorial mention of death throughout the chapters on the First World War.

From analysis of the textbooks, it can be deduced that they do not show the deaths, but concentrate on the economic aspects and on the actions of nations. The real subjects who died in combat are not mentioned. The names written in the books are only those of governing authorities.

\section{Women in the narratives on the First World War}

The question of gender is an issue that cuts across school life and constitutes a relevant theme for debate in the classroom. In this respect, we sought to know what the textbooks say regarding women and men in the First World War. To do so, initially, we quantified the illustrations that carry human figures, with the results shown in Table 4.

Table 4 - Number of figures with people present, highlighting those of the female gender in the chapters on the First World War in the textbooks analyzed, in accordance with the country of publication.

\begin{tabular}{l|c|c}
\hline $\begin{array}{c}\text { Country of publication of the } \\
\text { textbook analyzed }\end{array}$ & $\begin{array}{c}\text { Total figures with people of } \\
\text { either gender (male/female) }\end{array}$ & $\begin{array}{c}\text { Figures with people of the } \\
\text { female gender }\end{array}$ \\
\hline Argentina & 09 & 02 \\
\hline Chile & 01 & 01 \\
\hline Brazil & 04 & 01 \\
\hline Mexico & 06 & 00 \\
\hline United Kingdom & 03 & 00 \\
\hline Total & $\mathbf{2 3}$ & $\mathbf{0 4}$ \\
\hline
\end{tabular}

Source: Prepared by the authors.

${ }^{5}$ From the original in Portuguese: "A Primeira Guerra mundial foi um conflito que utilizou largamente o sistema de trincheiras. Na foto, soldados búlgaros, durante refeição, em trincheira no front do norte da Bulgária, em 1917".

${ }^{6}$ From the original in Portuguese: "Soldados franceses fazendo refeição na trincheira, durante a Primeira Guerra Mundial".

${ }^{7}$ From the original in Spanish: "Soldados británicos em las trincheras capturadas a los alemanes". 
It can be deduced from the data presented in Table 4 that only $17.4 \%$ of the figures showed females, which is an indication of the small representation that women received in the theme and in the textbooks analyzed. However, even more significantly, of this total of four pictures, women are highlighted in only one. This photograph, which does not have a caption, was presented in the introduction to the chapter on the First World War in the Chilean book (SÁNCHEZ CÓRDOVA, 2009) and it shows a group of women working in an environment that appears to be a center for sorting correspondence.

The other pictures, for their part, show women outside of the central camp, that is, at the battlefront or even acting in the medical corp. As indicated by Jensen (2008), the activity of women in the First World War was significant and exhibits three main forms of mobilization throughout the conflict - "women-at-arms, women physicians, and women nurses". ${ }^{8}$ In this respect, Hämmerle et al (2014) discuss the range of female activity and the consequent silence about it in history. The other figures show women only taking part in the scene in which men are at the center of attention.

Even the historical fact indicated by the five books as the trigger for the war, the assassination of the heir to the Austro-Hungarian throne, Franz Ferdinand, eliminates the presence of his wife, who was also a victim of the attack. Only the Argentinian book presents a figure that shows the couple. However, the name Sophie, Duchess of Hohenberg, is absent from all the books, but the name of the assassin is always mentioned.

In relation to textual information, only three books mention women, the Argentinian (PIGNA et al, 2010), the Chilean (SÁNCHEZ CÓRDOVA et al, 2009), and the book from the United Kingdom (FARMER, 2009). Only the Argentinian book gives greater treatment to women, with a specific part of the text entitled "The role of women in the conflict" (PIGNA et al, 2010, p. 95) ${ }^{9}$, and the following excerpt stands out:

In the face of the consummate reality of equality and through a continuous struggle, women began to obtain the right to vote. They indicated that if they were equal for working and struggling, they should also be for voting (PIGNA et al, 2010, p. 95) ${ }^{10}$.

This relationship between the activity of women in the First World War and their consequent social conquests after the end of it also appears in the British textbook: "During the war some women had done men's jobs - and done them as well as men" (FARMER, 2009, p. 103). In the Chilean book, this theme is treated in the following manner: "In addition, women's liberation is a consequence of the First World War" (SÁNCHEZ CÓRDOVA et al, 2009, p. 109) ${ }^{11}$.

It may be deduced from the excerpts highlighted that at the end of the conflict women gained space in the work market. However, the observations made in the work organized by Hämmerle et al (2014) indicate the opposite, upon observing that many

\footnotetext{
8 "Mulheres com armas, mulheres-médicos e mulheres-enfermeiras" (Our translation). The first are the women who during the war period began to handle arms; whereas women as doctors and nurses ended up being mobilized on the European front.

9 From the original in Spanish: "El rol de la mujer en el conflito".

10 From the original in Spanish: "Ante la realidad consumada de la igualdad y a través de una lucha permanente, las mujeres comenzaron a obtener el voto. Señalaban que si eran iguales para trabajar y luchar, deberían serlo para votar".

${ }^{11}$ From the original in Spanish: "También la liberación de la mujer es una consecuencia de la Primera Guerra Mundial".
} 
conquests were withdrawn in the following years. Only the British book makes brief mention of this fact with the expression, "However, arguably women were little more than cheap labor during the war. After 1918 most women returned, quite gladly in most cases, to their previous domestic roles" (FARMER, 2009, p. 103).

The textbooks analyzed indicate that the First World War was a conflict developed by men, commanded by them, without women acting in any way as protagonists. The main idea is maintaining women as figurative elements who participated only marginally, giving support to those who really fought and created the conflict, the men. The construction of an androcentric conflict prevails.

\section{Narrative construction in regard to the conflict}

Since these are textbooks, there is a concern with the manner of presenting the content. After all, they are made for the defined purpose of getting into the hands of students and being used in the classroom. Consequently, the narratives about the conflict contain abbreviations, choice of items to be discussed, events to be cited, and some to be omitted. These choices are clear when the books are compared. Thus, in this final part, we will trace an overall path through the text of the five books, observing, in a comparative manner, how the narrative about the First World War evolves. The first striking feature was the similarity of the structure of the narrative text, based on the triad antecedents/cause, development, and consequences, which was maintained by the five books. Each one made small changes in relation to the terms used, but it is possible to organize them in this sequence. Thus, we construct Table 5, systematizing the different titles and subtitles used in the books analyzed.

Table 5 - Reproduction of the titles and subtitles used in the chapters about the First World War in the textbooks analyzed.

\begin{tabular}{|l|l|l|l|}
\hline Country & \multicolumn{1}{|c|}{ Antecedents/causes } & \multicolumn{1}{c|}{ Development } & \multicolumn{1}{c|}{ Consequences } \\
\hline Argentina & $\begin{array}{l}\text { The industrialized countries in 1914. } \\
\text { Economy and society in Europe before } \\
1914 . \\
\text { War and peace. } \\
\text { The Balkans, conflict zone. } \\
\text { Opposition to war. }\end{array}$ & $\begin{array}{l}\text { The beginning. } \\
\text { Development. }\end{array}$ & $\begin{array}{l}\text { The end. } \\
\text { The consequences. } \\
\text { The role of women in the } \\
\text { conflict. } \\
\text { The treaties and the } \\
\text { territories. }\end{array}$ \\
\hline Chile & $\begin{array}{l}\text { Antecedents: Armed Peace, the } \\
\text { imperialist rivalries, the alliance } \\
\text { systems, nationalism, Balkan and } \\
\text { Moroccan crises, the Sarajevo } \\
\text { incident. }\end{array}$ & $\begin{array}{l}\text { Outbreak of the } \\
\text { conflict. } \\
\text { Development of the } \\
\text { war. }\end{array}$ & $\begin{array}{l}\text { The consequences of } \\
\text { European war. } \\
\text { The Mexican revolution, } \\
\text { the Russian Revolution. }\end{array}$ \\
\hline Brazil & $\begin{array}{l}\text { The Belle époque. } \\
\text { Period of optimism and progress. } \\
\text { The antecedents of the war. } \\
\text { Bellicose nationalism. }\end{array}$ & $\begin{array}{l}\text { Four years of } \\
\text { destruction. } \\
\text { Trench warfare. }\end{array}$ & $\begin{array}{l}\text { The peace of Versailles. } \\
\text { Mexico }\end{array}$ \\
$\begin{array}{l}\text { The dispute: antecedents, the } \\
\text { assassination in Sarajevo }\end{array}$ & $\begin{array}{l}\text { The dual fronts. } \\
\text { The war of 1915. } \\
\text { The war in 1916. } \\
\text { Last stages of the } \\
\text { war. }\end{array}$ & $\begin{array}{l}\text { Treaties. } \\
\text { Post-war. } \\
\text { Russian Republic. } \\
\text { The League of Nations, } \\
\text { France, England. } \\
\text { Italian fascism. }\end{array}$ \\
\hline
\end{tabular}




\begin{tabular}{|l|l|l|l|}
\hline Country & \multicolumn{1}{|c|}{ Antecedents/causes } & \multicolumn{1}{|c|}{ Development } & \multicolumn{1}{c|}{ Consequences } \\
\hline & & & $\begin{array}{l}\text { The Pontificate. } \\
\text { German nationalism. } \\
\text { Portugal and Spain. }\end{array}$ \\
\hline $\begin{array}{l}\text { United } \\
\text { Kingdom }\end{array}$ & $\begin{array}{l}\text { Colonial Rivalry. } \\
\text { Bismarck's Legacy. } \\
\text { European Relations: } 1890-1907 . \\
\text { Increasing Tension: } 1908-13, \text { The July } \\
\text { Crisis. } \\
\text { Which Country Was Most to Blame for } \\
\text { the First World War? } \\
\text { What Were the Main Causes of the } \\
\text { War? }\end{array}$ & $\begin{array}{l}\text { Why Did the War } \\
\text { Last so Long? }\end{array}$ & $\begin{array}{l}\text { Why Were the Central } \\
\text { Powers Defeated? } \\
\text { The Peace Settlement. }\end{array}$ \\
\end{tabular}

Source: Prepared by the authors.

The narrative is supported by historical facts that are repeated in the works, such as increasing rivalries among imperialist nations, above all between France and Germany, but also between Germany and Great Britain. The Brazilian book presents this in the following manner:

The imperialist dispute extended to the financial sphere: German loans at times were more advantageous than those of British bankers. In addition, the naval forces of the German Empire worried the English [...] (BRAICK; MOTA, 2013, p. 455) ${ }^{12}$.

The Argentinian book affirms that "The rivalry between England and Germany also emerged in the maritime area since the latter constructed an enormous war fleet, threatening English might" (PIGNA et al, 2010, p. 84) ${ }^{13}$. Another convergent point is what triggered the war, the assassination of the heir to the Austro-Hungarian throne, which undermined the already tense relations among the nations, breaking down diplomatic relations and giving rise to the conflict. The Mexican book describes the episode in the following manner:

It was under these circumstances, on June 28, 1914, during military maneuvers being undertaken in Bosnia, that the nephew of the emperor Franz Joseph, the archduke Franz Ferdinand, heir to the Austro-Hungarian throne, was assassinated by a Serbian student named Gravilo Princip (ALVEAR ACEVEDO, 1999, p. 248) ${ }^{14}$.

Other features are also repeated, such as the formation of the system of alliances, the Triple Alliance, the Triple Entente, and the Treaty of Versailles, at the end of combat. Nevertheless, upon examination of the works, what most drew attention was the way the book from the United Kingdom, despite being upheld by the same arguments, historical

12 From the original in Portuguese: "A disputa imperialista se estendia à esfera financeira: os empréstimos alemães às vezes eram mais vantajosos que os dos banqueiros britânicos. Além disso, a força naval do Impéro Alemão preocupava os ingleses [...]".

${ }^{13}$ From the original in Spanish: "La rivalidad entre Inglaterra y Alemania también se dio en el plano marítimo, ya que esta última construyó una enorme flota de guerra, amenazando el poderío inglês".

${ }^{14}$ From the original in Spanish: "Fue en estas circunstancias como, el 28 de junio de 1914, con motivo de unas maniobras militares que se realizaban en Bosnia, el sobrino del emperador Francisco José, el archiduque Francisco Fernando, heredero del trono de Austria-Hungría, fue asesinado por un estudiante de origen serbio llamado Gravilo Princip". 
facts, and cause/effect relationships as the Latin American books, introduces an interpretation not present in the others, the idea that the war was the result of an "accident", which was introduced in the narrative in the following manner:

Since 1914 historians have held many different views about the origins of the war. Some think that such a great event must have had great causes. But others have seen the war as simply accident, triggered by a series of unfortunate events in July 1914 (FARMER, 2009, p. 35).

Thus, the text of Farmer (2009) forms an interpretation that eliminates any idea of blame, or even reduces the belligerent actions of the nations that participate in the dispute, including his own country. He mitigates arguments that appear tacitly in other books by asserting that no nation desired the war. Although he defends the idea of an "accident" in the above excerpt, some pages later he concludes, "The war may have been an accident but it was also an accident waiting to happen" (FARMER, 2009, p. 35).

In this path of mitigating European conflicts, the narrative of the British book diverges from the others and, gradually, softens the arguments common to all the books. In that bent, the First World War gains divergent interpretations based on the same historical events, beginning with the origins of the conflict. According to the Chilean book, "This situation [rivalry among the powers] raised fear in the imperialist governments that the regions they controlled would be wrested away from them" (SÁNCHEZ CÓRDOVA et al, 2009, p. 113) ${ }^{15}$.

This statement showed that the imperialist nations feared losing their colonial empires and that their disputes stirred up the ill feelings among them. The Brazilian book adds, "The countries sought to obtain the most advanced armaments, driven on by militarist propaganda and their imperialist ambitions" (BRAICK; MOTA, 2013, p. 454) ${ }^{16}$.

Farmer (2009) does not deny the imperialist politics and the incitement of emerging rivalries among the European nations, but he minimizes the importance of it by adding the argument of non-intentionality. Regarding the construction of the British Empire, he states, "While Britain annexed large territories, it did so somewhat reluctantly" (FARMER, 2009, p. 37). He emphasizes that even the struggles for Africa were not deliberated actions of the European states but resulted from isolated actions. "The creation of a vast French empire in West Africa, for example, was largely the work of the French colonial army, often acting contrary to instructions from Paris" (FARMER, 2009, p. 39). He ends with the following text:

In the colonial stampede, actions were often simply reactions to particular circumstances - not clearly rationalized policies [...] The impetus for expansion frequently came from men on the spot, missionaries, soldiers, explorers and businessmen, rather than from political leaders in Europe (FARMER, 2009, p. 38).

In the case of France, those guilty of the imperialist actions had been the colonial armies, and England, for its part, annexed territories without desiring to. The nation states were not the agents that prepared the conflict but rather isolated elements did, and, finally,

\footnotetext{
15 From the original in Spanish: "Tal situación (rivalidades entre las potencias) provocó em los gobiernos imperialistas el temor de que les fueran arrebatadas las zonas que tenían bajo su control".

16 From the original in Portuguese: "Os países procuravam obter os armamentos mais avançados, impulsionados pela propaganda militarista e de suas ambições imperialistas".
} 
the nations entered in combat to resolve a problem that they did not create. In regard to these rivalries, he ends up constructing a positive view:

Colonial rivalries, on occasion, seriously damage relations between the European powers. Arguably, however, these rivalries provided a safety valve through which the great powers could let off steam, at a safe distance, without harming each other too much (FARMER, 2009, p. 43).

In the Argentinian book, for its part, in agreement with the others, these rivalries led to the establishment of a policy of alliances and to an armament race, as follows:

Another cause (of the conflict), was the armament race. A way of showing power in the face of economic rivals was to have powerful armies. The military budgets of the great powers increased considerably [...] (PIGNA et al, 2010, p. 87) ${ }^{17}$.

These rivalries, according to Mexican and Brazilian books, were also decisive for the beginning of the large scale conflict as they involved the members of the alliances.

Germany, for its part, according to the terms of the Triple Alliance and as an ally of Austria-Hungary, felt obligated to act, abiding by the agreement, and it addressed Russia to oblige it to cease military preparations. [...] The French army began to mobilize on August 1 and, on the same date, Germany declared war on Russia, and on August 4 on France (ALVEAR ACEVEZO, 1999, p. 249) ${ }^{18}$.

Little by little, the conflict became worldwide. The system of alliances drew other countries into the struggle (BRAICK; MOTA, 2013, p. 454) ${ }^{19}$.

Thus, if for the Mexican book, just as for the Argentinian, Brazilian, and Chilean books, the rivalries among the powers and the formation of alliances played a decisive role in the conflict, for the English book there is another interpretation:

Interestingly, while many historians after 1914 argued that the alliance system made war inevitable, many contemporaries believed that, by creating a balance of power, it helped maintain peace (FARMER, 2009, p. 61).

This is a recurrent idea in the text of Farmer (2009); he does not reject the argument that the policy of alliances had an important role in the outbreak of war. Nevertheless, he inserts the element of doubt, allowing the reader to question whether these alliances were really decisive for the outbreak of war. The Latin American books postulate the defensive function of the alliances, as seen in the Chilean book, but allow a positive interpretation:

Alliances were established among some European countries for the purpose of creating diplomatic connections that would strengthen the relations among the

\footnotetext{
17 From the original in Spanish: "Otra causa (del conflicto) [...], fue la carrera armamentista. Una forma de demostrar poder frente a los competidores económicos era tener poderosos ejércitos. Los presupuestos militares de las potencias aumentaron considerablemente".

${ }^{18}$ From the original in Spanish: "Alemania, por su parte, de acuerdo con los términos de la Triple Alianza, y como aliada de Austro-Hungría, se sintió en la obligación de actuar, y a ese efecto se dirigió a Rusia para conminaría a cesar los preparativos militares. [...] El ejército de Francia comenzó a movilizarse el 1 de agosto y, en la misma fecha, Alemania le declaró la guerra a Rusia, el día 4 a Francia".

19 From the original in Portuguese: "Aos poucos, o conflito, tornou-se mundial. O sistema de alianças arrastou outros países à luta".
} 
capitalist powers, which committed them to mutual defense in the case of aggression (SÁNCHEZ CÓRDOVA et al, 2009, p. 113) ${ }^{20}$.

This excerpt from the Chilean book is placed under the title "Antecedents", citing the alliances as one of the causes of the conflict, and not in order to "maintain peace", as Farmer (2009) suggests. In this respect, the argument of an "accident" is prominent on the pages that explain the beginning of the war, but the conciliatory tone remains. However, in relation to the development of the conflict and the consequences, the differences are only in relation to the events chosen to be narrated, with many similarities.

The development of the conflict is highlighted in the five works. The trenches are the object of pictorial representations in the Brazilian and Argentinian books, but they are textually cited in all the books, as in the following notable examples:

Trench warfare acquired the following characteristics:

[...] It increased mortality.

[...] They used new warfare material: inflammable liquid, toxic gases, etc. (SÁNCHEZ CÓRDOVA et al, 2009, p. 120) ${ }^{21}$.

[...] the war which exhibited movement in its first months came to be trench warfare, without either of the sides having enough power to defeat and drive out the opponent (ALVEAR ACEVEDO, 1999, p. 251) 22.

Conditions in the trenches were hellish. Soldiers suffered from trench foot, lice, rats, shelling, snipers and enemy raids (FARMER, 2009, p. 73).

In this development of the conflict, an element in the Mexican book stood out from the others, because the Mexican book is unique in mentioning any religious interference. This religious interference is considered by Alvear Acevedo (1999) when he gives visibility to the activity of the Vatican and Pope Benedict XV, namely:

In fact, the chancellery that made the greatest effort for peace to return to Earth was the Vatican. The Pope and his secretary of state, monsignor Gasparri, and his nearest colleague, monsignor Pacelli, did everything in their power to avoid the conflict (ALVEAR ACEVEZO, 1999, p. 250) ${ }^{23}$.

Furthermore, the author argues that the failed attempts at peace by the Vatican were motivated by the "anticlericalism of the Frenchman Clemenceau"4" and by the "Protestantism of the German Ludendorff"25" (ALVEAR ACEVEZO, 1999, p. 251).

${ }^{20}$ From the original in Spanish: "Se llevaron a cabo alianzas entre algunos países europeos, que tuvieron la finalidad de crear ligas diplomáticas que fortalecieran las relaciones entre potencias capitalistas, las cuales se comprometían a defenderse mutuamente en caso de agresión".

${ }^{21}$ From the original in Spanish: "La guerra de trincheras adquirió las siguientes características:

- [...] Aumentó la mortandad.

- [...] Se utilizaron nuevos materiales bélicos: líquidos flamables, gases tóxicos, etcétera".

${ }^{22}$ From the original in Spanish: "[...] la guerra, que fue de movimientos en sus primeros meses, pasó a ser una de trincheras, sin que ni unos ni otros de los contendientes contaran con fuerzas suficientes para vencer ni para desalojar a los contrários".

${ }^{23}$ From the original in Spanish: "En realidad, la cancillería que más trabajó para que la paz llegara de nuevo a la Tierra, fue la de Vaticano. El Papa y su secretario de Estado, monseñor Gasparri, y el cercano colaborador de éste, monseñor Pacelli, hicieron cuanto les fue dable para que la lucha no siguiera adelante".

${ }^{24}$ From the original in Spanish: "anticlericalismo del francés Clemenceau".

${ }^{25}$ From the original in Spanish: "protestantismo del alemán Ludendorff". 
In regard to the consequences, the most cited facts are the Treaty of Versailles and the Treaty of Saint Germain. There is no determination of those guilty for the conflict; only the British book concludes, "[...] while not being entirely responsible for the war, it does seem that Germany was more to blame than any other power" (FARMER, 2009, p. 60).

At the end of the chapters of the books analyzed, new problems to be resolved are indicated, showing that the war had not brought benefits. The Argentinian book alerts that "The war especially affected the farming and working classes, who made up the majority of those sent to the battlefront ${ }^{26 "}$ (PIGNA et al, 2010, p. 93), as an attempt at indicating a path of internal difficulties in the most varied nations and highlighting that, for the general population, the end of the war did not bring about any gains. However, we perceive that the direction of the texts, at the end of the chapters, indicates the possibility of a new war, and the authors of the Chilean book express it this way: "The peace treaties did not assist in solving the problems that had given rise to the war; on the contrary, they introduced new problems [... $]^{27 "}$ (SÁNCHEZ, 2009, p. 120).

\section{Final considerations}

At the end of this investigative endeavor, in which our main intention was to learn the manner that the theme of the First World War was dealt with in school textbooks in Latin American countries and the United Kingdom, we can see the predominance of a narrative construction built on the customary explanatory triad: antecedents, development, and consequences. There was also an emphasis on an androcentric discourse, upheld by great names and acts, from a Eurocentric perspective, even when the text came from Latin American authors. Possibly for student who had access to these textbooks, only the heads of state, with great abilities and powers, are worthy of memory, because the common subjects are absent from the narratives.

However, what made the investigation very interesting was the perceived dissonance in the interpretations made in the Argentinian, Chilean, Brazilian, and Mexican books as compared to the British book. Even though all the books present the theme of the First World War based on common historical events, the British author differently interprets the conflict as the result of an accident.

In this regard, Chopin (2004, p. 557), within the observation that "every controversy is deliberately eliminated from school literature", allows the understanding that the narratives contained in the textbooks, produced for consumption in a national environment and within schools, avoid taking on controversial positions. The careful textual presentation of the British book may be understood from that perspective since discussions on the First World War are more present in European territory than in Latin America.

In textbooks examined from the other side of the Atlantic, for their part, these concerns are not present, and cause/effect relations are constructed more directly. In this textual orientation, the Latin American books ended up constructing a narrative of a conflict designated as worldwide; however, evidence was not provided of the effective participation of the nations in which these books were published.

\footnotetext{
${ }^{26}$ From the original in Spanish: "La guerra afectó, especialmente, a las clases campesinas y obreras que, en su mayoría, fueron enviadas al frente".

${ }^{27}$ From the original in Spanish: "Los tratados de paz no sirvieron para solucionar los problemas que había originado la guerra; por contrario, plantearon nuevos".
} 
Evidently, this article is not intended to establish a value judgment on the works analyzed, but to lead to a reflection on how they dealt with the theme of the First World War. We did this through a comparative analysis that, at least in the sphere of objectives, as Chervel (1990) teaches, allowed us to understand what was prescribed for teaching the history of the First World War. In spite of all the narrative strategies typical of textbooks for basic education, with their silence on corrosive themes, at the end of examination of the five school textbooks, the understanding remains of the losses from a war and the horrors that nations may commit.

\section{References}

ALBERT, B. South America and the First World War. The impact of the war on Brazil, Argentina, Peru and Chile. Cambridge: Cambridge University Press, 2002.

ALVEAR ACEVEDO, C. Historia Universal Contemporánea. México: Limusa, 1999.

APPLE, M. W. Cultura e Comércio do Livro Didático. In: Trabalho Docente e Textos: Economia Política das Relações de Classe e de Gênero em Educação. Porto Alegre: Artes Médicas. 1995. p. 81-105.

BRAICK, P. R.; MOTA, M. B. História: das cavernas ao terceiro milênio. São Paulo: Moderna, 2013.

CÂMARA BRASILEIRA DO LIVRO. Comportamento do Setor Editorial Brasileiro1990/1996.

CHERVEL, André. História das Disciplinas Escolares: reflexões sobre um campo de pesquisa. Porto Alegre/RS. Teoria e Educação, Pannonica, Porto Alegre, n. 2, 1990, p. 177-229.

CHOPIN, A. História dos livros e das edições didáticas: sobre o estado da arte. Revista Educação e Pesquisa. São Paulo: USP. n.30. 2004.

FARMER, A. An Introduction to Modern European History 1890-1990. London: Hodeer Education, 2009.

FAUSTO, B. História do Brasil. São Paulo: EDUSP, 2012.

FOSTER, S. Whose history? Portrayal of immigrant groups in U.S. history textbooks, 1800-present. In: S. Foster \& K. Crawford (Eds.), What shall we teach the children? International perspectives on school history textbooks (p. 155-178). Greenwich: Information Age, 2006.

GATTI JR., D. A Escrita Escolar da História: livro didático e ensino no Brasil (1970-1990). Bauru/SP: Edusc; Uberlândia/MG: Edufu. 2004.

HÄMMERLE, C.; ÜBEREGGER, O.; ZAAR, B. B. Gender and the First World War. London: Palgrave Macmillan, 2014.

HOBSBAWM, E. Era dos Extremos. O breve século XX (1914-1991). São Paulo: Companhia das Letras, 2008.

JENSEN, K. Mobilizing Minerva: American Women in the First World War. Illinois: Urbana: University of Illinois, 2008.

PILCHER, J. M. Mexico, Role in the War. The European Powers in the First World War: An Encyclopedia, TUCKER, S. C. New York: Routledge 2013.

PIGNA, F. et.al. Historia. El mundo contemporáneo. Buenos Aires: A-Z, 2010. 
SÁNCHEZ CÓRDOVA, H. et al. Historia universal. México: Pearson Educación, 2009.

ROGÉRIO JUSTINO é doutorando em Educação no Programa de Pós-Graduação em Educação da Universidade de Brasília. Mestre em Educação pelo Programa de PósGraduação em Educação da Universidade Federal de Uberlândia. Professor do Instituto Federal de Educação, Ciência e Tecnologia do Tocantins, Campi Paraíso do Tocantins.

Address: Av. Coronel Antônio Alves Pereira, 896 - Centro - 38400-104 - Uberlândia/MG Brasil

E-mail: rogerio.justino@gmail.com

DÉCIO GATTI JÚNIOR é Doutor em Educação: História e Filosofia da Educação pela Pontifícia Universidade Católica de São Paulo, com estágio de pós-doutorado concluído na Faculdade de Educação da Universidade de São Paulo. Professor Titular de História da Educação na Faculdade de Educação da Universidade Federal de Uberlândia. Bolsista de Produtividade em Pesquisa do CNPq (Nível 1C). Beneficiário do Edital Universal do CNPq e do Programa Pesquisador Mineiro da Fapemig.

Address: Rua Marques Póvoa, 513, apto. 1102 - 38400-438 - Uberlândia/MG - Brasil E-mail: degatti@ufu.br

Recebido em 25 de outubro de 2016.

Aceito em 10 de janeiro de 2017. 